\title{
Materialism Precedes Murder: Saul Bellow's Seize the Day
}

\author{
Joyshree Deb \\ Department of English, Sylhet International University, Bangladesh.
}

\begin{abstract}
The society that Saul Bellow (1915-2005) depicts in his novel Seize the Day (1956) is overwhelmed with materialism, which brings ruin in common people's fate, and eventually is to be murdered everywhere. Here, the word 'Murder' doesn't mean 'the unlawful killing of one human by other, especially with premeditated malice"; rather it is symbolically used to express the slaying of human sense, belief, love and passion, in a word humanity. In the contemporary American capitalist society money stands as a mammon to man. Therefore, the present article has attempted to discuss the relationship between materialism and murder in Bellow's merciless society and the cause of this psychological murder. Our protagonist, Tommy Wilhelm can't adapt himself in this materialistic trench of society, and is to be detached from his father, wife, children, and from rest of the world. In fact, this paper tries to discover how materialism expunges family relationship as well as human relationship and this very relationship is to be murdered as well.
\end{abstract}

Keywords: Saul Bellow, Money, Murder, Materialism, Society, Capitalism.

\section{Introduction}

Tommy Wilhelm is, in his mid-forties, temporarily living in the Hotel Gloriana of New York City and in the same hotel his father has taken residence for several years, but in the different floors. Dr. Adler, father of Wilhelm, doesn't show any affection for his issue, Wilhelm and Cathrine. As Wilhelm is jobless, he is always seeking assistance from father believing that if his father supports him or stand by his side, he will easily overcome his all lacking. Even he doesn't get love from his wife Margaret, rather she always tries to keep his husband under pressure just for money. Wilhelm, in such a situation, believes and depends on a father- figure man, Tamkin who soon escapes taking the last means of Wilhelm. So, the murder of family relationship is symbolized through the parents-children relationship and the husband-wife relationship whereas the murder of humanity is symbolized through Wilhelm - Tamkin relationship. Materialism stands as a catalyst of these murders. Generally the word "materialism" refers to the theory or attitude that physical well-being and worldly possessions constitute and the greatest good and highest value in life (The American Heritage Dictionary of the English Language, 2000, p.1080); that means in short "to act as a realist". So, in Seize the Day except Tommy, each and every character is materialistic and they are being made for material success, spiritual world is totally invisible to them. They are busy to get material success even if it is necessary to murder a person. Tommy's whole life is full of mistake. Choosing a Hollywood career is his first mistake and his marriage against his parents' wish is another mistake in his life. But the most crucial mistake is to keep trust on Tamkin and deliver his last seven hundred dollars for which he is to be murdered. Tamkin obtains material success by exploiting the last means of Tommy. Material success is the only reality of man's life in post- war world. Materialism acts as a sucker which sucks the life blood. Materialism evaporates the consciousness of mankind and manifests to slay the human being. Murder becomes so an easy deed that it blows all over the society and amalgamates with the breath of people. Concerning the situation, Miller is heard saying "If only we could stop murdering one another we could be a wonderfully humorous species" (Glencoe, 2000, p.911). Therefore, the rise of materialistic world annihilates the soften side of human mind, persuade to murder the fellow man, and it seems inevitable to be murdered whether psychologically or physically.

\section{Murder In Seize The Day}

In Seize the Day, Saul Bellow Might has tried to highlight the way of life in the Capitalist America, where materialism is the prominent modern phenomenon which probably begins due to American Dream. Those who couldn't resort the majesty of materialism; they can't retain their existence, loss easy relationship with the family members, and with the people of society. They may be alive physically yet murdered psychologically. In this society, there are particularly found two types of murder - murder of family relationship and murder of human relationship. Wilhelm is the rent asunder man of capitalism, pushes the American Dream into nightmare, as he craves for success but don't have knowledge of success, rather devoid of inner resources. He always keeps himself self- absorbed; therefore degrade the connection with his father, wife, as well as children, and becomes an easy prey of dubious agent of society too. 
Bringing up during the Great Depression, Saul Bellow's writing primarily focuses on the struggles faced by the less fortunate Americans. His pale and desolate description of building and street scene of the Chicago emphasizes the colour less life and time of countless Americans. What makes Bellow so renown for is not only for his writing about the Depression, but also his ability to describe how the Depression felt like, what the impact of the Depression on average Americans. "Not all Americans participated equally in these expanding life opportunities and in the growing economic prosperity. The image and reality of overall economic prosperity and the upward mobility it provided for many white Americans was not lost on those who had largely been excluded from the full meaning of the American Dream, both before and after the war" (The post-war United States, para 3). The title of the novel itself suggests the way about the success of American dream. The title has been derived from one of the poem of poet Horace.

Dum loquimur, fugerit invida actas;

Carpe diem, quam minimum credula postero.

Carpe diem means seize the day or utilizing the time that is going on every moment and by the way the success could only be possible. Bellow tries to portray a scenario of the post-war contemporary America where most of the people couldn't seize the time and waiting for success in future which is really a futile thought or dream. Our protagonist, Tommy Wilhelm also dives down in the ocean of nightmare.

In this postwar period, life become well than it had been. American dream is for many families a reality. Those who were serious about their dream, they easily attained success. But those who couldn't realize the dignity of dream and the way of success had to suffer in the long run. "Among post-world war II American novels his are the ones that best present the problems of the modern urban dweller in the search for identity. His heroes are rootless or rooted to a past that no longer seems relevant to the present" (Perkins, G. and Perkins, B., 1999, p.2032). Bellow dramatizes a moral crisis, arising from man's dehumanization which, he believes, is responsible for an ongoing dichotomy in the modern world. Bellow recounts the traumatic condition of society, loss of love, and breakdown of humanity. Seize the Day is an artistic exploration of the devaluation of human relationship and its causes as well as effects in a post-war capitalist society. Materialism or money causes the degradation of human relationship, concisely alienation, meanness, as well as loss of human love and passion. In the city of New York, people are commercial, supercilious; there is no love and understanding except frustration. After the World War II, family bondage is falling apart due to materialism. It is tremendously ironical that a person feels alienation within a family or within society. Materialism makes a gap in the family relationship as well as human relationship. The human relationship is that of artificial and superficial. None is care for others. The city dwellers are busy with their own business and the warmth of human relationship seems to be murdered. About the morbidity of city life, once Wilhelm meditates "especially in New York - the end of the world, with its complexity and machinery, bricks and tubes, wires and stones, holes and heights. And was everybody crazy here? Every other man spoke a language entirely his own, which he had figured out by private thinking; he had his own ideas and peculiar ways" (Bellow, 1996, p.83). A modern man is imprisoned within himself, alienated from others and from myself also. In the after math of World War II, satisfactory human relationship degrades with the presence of intense materialism. New York embodies as 'unreal city' (Perkins, G., and Perkins, B., 1999, p.1381), as T.S. Eliot terms it in The Waste Land, where materialism triumph over human relationship. Seize the Day is "a snapshot of life, exposing the burdens of modern man in a world where wealth and power have come to mean everything'" (Roof Beam reader, 2012, para. 1).

"The central characters of Bellow's novels are often intellectual, philosophical, and divided by cultures, ideas, money, and relationships. Seize the Day begins: "When it came to concealing his troubles, Tommy Wilhelm was not less capable than the next fellow" (Bellow, 1996, p.3). It is as though Bellow states the antithesis of Tommy Wilhelm's condition, since he is not, in the least, remote from his problems" (Vaughan, 2005, para 7). Tommy Wilhelm is the protagonist of the novel who is a looser and ignominious defeater in a money-worshipping world. In the post-war American capitalist society money is the only god to them through which they want to attain the material success in life. Only the realistic and materialistic American can survive their existence as the motto of American dream is "Earning success by any means" (Green's blog, 2012, para 6).

But Tommy always bears a kind of romantic notion in his mind. He is totally misfit for the competition. He can neither comprehend nor adapt himself to the changes of the society where he belongs. That's why he is "an unsuccessful man of mid-forties is dependent on his father even at this age. This clearly symbolizes the post World War youths who failed to understand the message of the American Dream and failed thereby" (Green's blog, 2012, para 6). Sometimes we see that Tommy can comprehend the lacking of quality to succeed in this world what he should have. In his novel, New York is to be represented as the whole money-

cultured world where everything is determined by money. Tommy falls in whirl wind of the society and suffers from his inability to adapt himself in this capitalist world where humanistic sense is to be murdered. Tommy says "The world is full of murderers. So it's not the world. It's a kind of hell" (Bellow, 1996, p.71). In the 
materialistic world of New York, Tommy feels out of place and he is fully aware of his isolation. In the sea of crowd, he has to talk to himself as there is none who will spend a few times to listen his anguish. He always trusts the wrong people. He makes the same mistake again and again. Though he is a habitant of "wealth-driven world" (DelVesco, 2011), he is helpless, poor, unsuccessful and unemployed. He believes his whole existence has been a string of mistakes because he puts too much faith in rotten people. Consequently, he has left nothing at the end. Tommy even prays to get this point across "Oh, God. Let me out of my trouble. Let me out of my thoughts, and let me do something better with myself. For all the time I have wasted I am very sorry. Let me out of this clutch and into a different life. For I am all balled up. Have mercy" (Bellow, 1996, p.26). The terrible condition of Wilhelm reminds us James J. Braddock - the hero of the movie "Cinderella Man"- whose career as a prize-fighter is appeared to be finished, lost everything in stock market and now broken-down completely, unable to pay the bills and maintain his family.

Wilhelm and his "exacting diagnostician-father" (Shatzky and Taub, 1997, p.32) Dr. Adler live under the same roof, but in separate room which is enough to prove the condition of parent - child relationship. Wilhelm detaches from his father for two reasons: firstly he quits school and changes his name (against his parents' expectation) to go to Hollywood; Secondly he seeks to divorce his wife and marry a Catholic girlfriend. In the first three sections we see the conversation of Wilhelm with his father over Wilhelm's lifestyle, taking pills and his mother's death. But Adler being worshipper of materialism and German mannerisms is so indifferent that he could not remind his wife's death date even. Their relationship goes down in such a step that Wilhelm doesn't feel any happiness in his father's presence. Even the situation turns to quarrel when they discuss the family matters. Wilhelm thinks -"You were set free when Ma died. You wanted to forget her. You'd like to get rid of Catherine, too. Me, too. You're not kidding anyone" (Bellow, 1996, p. 29). Henceforth once responding to the question of Tamkin, once Wilhelm pronounces "Of course, of course. I love him. My father. My mother-" (Bellow, 1996, p.92). Adler and Tommy stand as two different generations. "This of course brings forth the cardinal conflict: the dominating, respectable, independent, secure father against the oppressed, debased, dependent, insecure son" (Goldman, 1983. p.66). Adler symbolizes as a successful character of postwar America whereas Tommy symbolizes as an unsuccessful man who can't cope with the materialistic world. Dr. Adler is realistic, unsympathetic and practical. He believes in American dream and success and determines his own fate. He stands as a counterpoint of Wilhelm. The estrangement between Wilhelm and his father is the result of money. If Wilhelm had much money, his father might not drive him away. Not only for money itself, but also for getting father's love, Wilhelm always hovers over money as it is expressed in his passionate outburst-“" No, but you hate me. And if I had money you wouldn't. By God, you have to admit it. The money makes the difference. Then we would be a fine father and son, if I was a credit to you--so you could boast and brag about me all over the hotel. But I'm not the right type of son. I'm too old and too unlucky" (Bellow, 1996, p.55). Adler stands as the typical American materialistic father. When Tommy appears at the door of his father seeking compassion and assistance, he has furiously been rejected -

"I'll see you dead, Wilky, by Christ; before I let you do that to me. Go away from me now. It's torture for me to look at you, you slob!" (Bellow, 1996, p.110).

Adler eschews the heartiest cry of Tommy. He could have stretched his helping hand to his son or at least give him convulsion. It may have happened that Tommy avoids the prohibition of his parents to join in Hollywood. But he might have obeyed the suggestion of Adler. Perhaps it was Tommy's emotional stage when he would like to be an actor. If Adler stands by Tommy as a guardian, mentor, advisor and affectionate father, Tommy would not incline to this shrewd person. We see that Tommy can comprehend what is the real face of Tamkin, but forgets at the very moment thinking that -

“At least Tamkin sympathies with me and tries to give me a hand, whereas Dad doesn't to be disturbed." (Bellow, 1996, p.11)

Concerned with many aspects of the American Dream, Wilhelm, rejected by his own father, helplessly throws himself on the mercy of a number of father figures. The most significant among them is Dr. Tamkin (Shatzky and Taub, 1997, p.32). When Wilhelm deprives from his father's love and affection, he then sets himself in quest of an understanding, loving heart, father- figure for which he becomes an easy victim of Tamkin. Tamkin can conceive the heartiest agony of Wilhelm and lacking of his life, he shows love and affection for Wilhelm to make him trustworthy. We must agree with Anu Shukla who mentions in his article "The world of Saul Bellow" that -

Tamkin becomes Tommy Wilhelm's spiritual father. Tommy looks on him as an "ideal Father", who understands the relationship of fathers and sons though later on he discovers that he is both narcissistic and materialistic (as cited in Shukla, S., and Shukla, A., 2006. p. 168). 
Eventually, Wilhelm turns as a puppet at Tamkin's hand and Tamkin ceases every scope to dupe and exploit Wilhelm. In such a capitalist and competitive society, there is not a bit place for simple-hearted, passionate person, they could easily fall in deceiver's eyes and lost his last means. In the pitiful condition, none sympathies with others. We see, in the novel, none feels bit sympathy for the miserable condition of Tommy. "The only person who is willing to take time to hear Wilhelm is the mysterious psychologist Dr. Tamkin" (The middle age, para 6). Actually we cannot address this feeling as "sympathy"; rather it is an initial step for preparation of murder. Showing sympathetic side, he tries to manage a friendly environment to murder a person. More specifically, whatever Tamkin shows to Tommy are not to be called as sympathy, rather it's a pretension for exploiting the last means of a man to get material success. In spite of his failure to understand Tamkin, he listens Tamkin's advice, suggestion and logic and has established a sensitive bond- "That the doctor cared about him pleased him, wish him well. Kindness, mercy, he wanted" (Bellow, 1996, p.73). Tamkin persuades Wilhelm to invest his last means in lard business. But the trickster Tamkin cunningly escapes with all these money. In chapter IV, Tamkin introduces the idea of murder in money making. Tamkin gives the idea that -

"One fact should be clear to you by now. Money-making is aggression. That's the whole thing. The functionalistic explanation is the only one. People come to the market to kill. They say, 'I'm going to make a killing.' It's not accidental. Only they haven't got the genuine courage to kill, and they erect a symbol of it. The money. They make a killing by fantasy."

(Bellow, 1996, p.69)

These lines expose the irony that Tamkin has met with Tommy with the very same intention to make money by murdering Tommy. Money ruins the usual existence of Tommy as "money is of course destruct" (Bellow, 1996, p.77). Wilhelm can't comprehend the grim truth of Tamkin's poem and explaining the theory of real soul and pretender soul. At the same time, it will not be fair to tell that Wilhelm can't realize anything else; because we find Wilhelm heart is severely being filled up with suspicion about Tamkin's personality and intention. While Tamkin keeps Wilhelm attention away from selling, engaging into stories about his own dad and a woman, Wilhelm has shown to burst "Liar! Wilhelm inwardly called him. Nasty lies..... He's a puffed-up little bogus and humbug with smelly feet" (Bellow, 1996, p.95). Nevertheless, he erects conviction on Tamkin. Currently, we find him always in the midst of conscious and unconscious, that's preconscious. Therefore, Tamkin always keeps Wilhelm in a whirlwind of deep thought as well as hallucination and murders him mercilessly. It is need to refer that Wilhelm is not murdered physically, but psychologically. If he had enough consciousness in mind, he would not face this sequel at length. The mental state of Wilhelm makes us remind the name of a psychologist, Sigmund Freud (1856-1939). From Dr. C. George Boeree's article "Sigmund Freud" (2009, para 3), we come to know that S. Freud mentions the three stages of human mind — Id (unconscious), Superego (preconscious) and Ego (conscious). As the novel moves onward, we get the picture of Wilhelm's past life through his flashbacks, which was full of unconscious. At present, we can say that his mental state is in the stage of preconscious, since he believes and doubts Tamkin simultaneously, which leads him to be murdered. Although Tamkin murders Wilhelm psychologically, eloping with his last money, he helps to lead Wilhelm preconscious to conscious in future. But it is really a great matter of fact that, though he has come into consciousness, his survival is uncertain losing everything in life and faith as well. Let us remark the life sketch of Wilhelm through a diagram (Fig. 1).

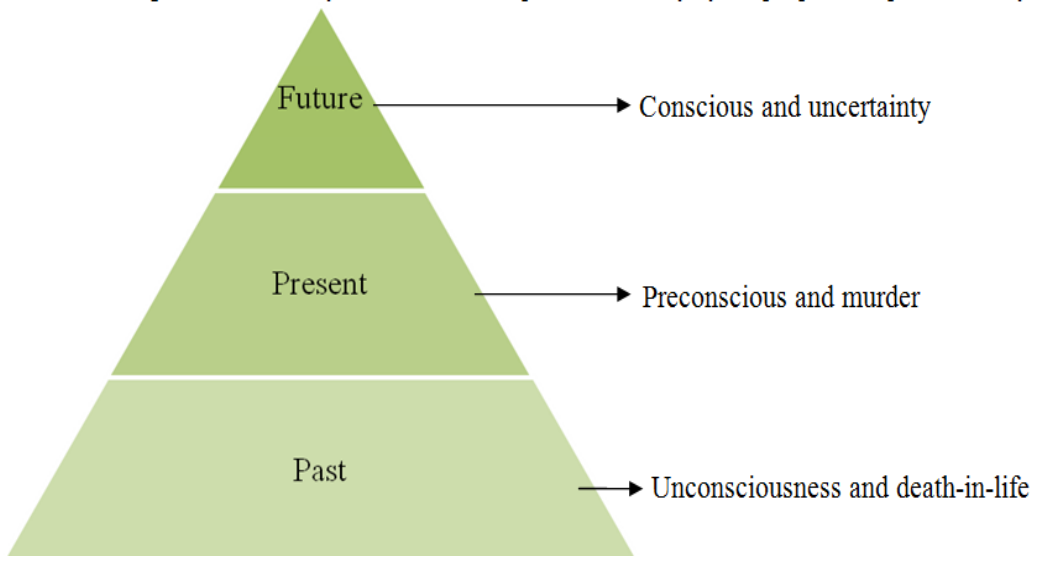

Figure 1: The Life sketch of Wilhelm

In the Capitalist society, people who are like Wilhelm, remain in unconscious and preconscious stage, they are destined to be duped and murdered. As stated before, Tamkin tells the theory of true and pretender soul - "The true soul is the one that pays the price. It suffers and gets sick, and it realizes that the pretender can't be 
loved. Because the pretender is a lie" (Bellow, 1996, p.71). Obviously, the true soul is none but Wilhelm himself who falls in trap of a pretender soul. This is the inevitable destination of Wilhelm, in a word for humanity. Old Rapport with his blindness presents as a symbolic character signifying that people are hankering after money even in his old age. His blindness symbolizes the blind pursuit of money by the people of Capitalist society.

Commercialism has driven away the compassion, love and emotion, even from the nuptial relationship. In the world of Seize the Day, this relationship is also thoroughly materialized where the word "love" is totally meaningless. Wilhelm's wife, Margaret doesn't allow him divorce, rather prolongs the process with increasing demands for money. Usually husband-wife relationship is based on love, emotion and attraction, but in Seize the Day Bellow presents how this loving and comprising nuptial relationship is turned to be a dissatisfaction and hostility. Because of Margaret, Wilhelm always stays under pressure. Margaret acts as an exploiter and murderer who ceaselessly not only exploiting the poor Wilhelm but also doesn't show any compassion in his severe plight. Being cheated by Tamkin, Wilhelm says to his wife "I'm at the end of my rope and feel that I'm suffocating. You don't want to be responsible for a person's destruction... I feel I'm about to burst" (Bellow, 1996, pp. 113-114); but his heartfelt agony doesn't help to shake her heart a bit.

Willy Loman, the character of Arthur Miller in Death of a Salesman (1949), seems twin brother of Wilhelm as they are mostly alike in their job, life speculation and cause of their catastrophe, can't prevent him from irresistible downfall. Like Wilhelm, Willy Loman feels intensity of emotion, simple at heart and considers the world to be so. Both Willy and Wilhelm are nearly similar when we think about their cause of failure and their ultimate doom. We can clearly comprehend that Willy lives in hallucination raring the false notion of American dream. He believes personal attractiveness is enough with a view to attaining success in life. As we hear Willy says to Biff, "Because the man who makes an appearance in the business world, the man who creates personal interest, is the man who gets ahead. Be liked and you will never want" (Miller, 1961, pp. 25-26). Both Willy and Tommy make mistake in their life and this very mistake turn them away from their family. Consequently Tommy is to be murdered in the hand of Tamkin because of money. Same way Willy commits suicide believing the insurance policy worth $\$ 20,000$ will be very helpful for his family. The suicide that is committed by Willy can be named as a kind of murder, that's self murder, as "all suicide is murder" (Bellow, 1996, p.71). So, just for material gratification of others, one is murdered physically and another psychologically.

After the Second World War, America started becoming a superpower based on capitalism. Regarding capitalism Karl Marx remarks that "the exploitation of one social class by another is seen especially in modern industrial capitalism, particularly in its unrestricted nineteenth century form. The result of this exploitation is alienation" (Berry, 2002, p.157). Dr. Tamkin seemingly persuades Wilhelm to invest in the market even though he himself has little capital. Though Tamkin talks much about the profit of lard and rye business, his intention is not to help Tommy, rather absorbs the last blood of his vain. At the end, we see that instead becoming a rich man, Tommy still remains exactly the same what he is. On the other hand, the money Tamkin takes from Tommy makes him even richer. However, by presenting these characters in his novel, Bellow might have tried to unveil the realistic influence of capitalism in the then American societies.

\section{Conclusion}

At last, Saul Bellow, through his novel Seize the Day, has attempted to show the $20^{\text {th }}$ century post-war American society where human fellow-feeling is trivial to materialism and owing to material success, people are being murdered. The emotional sterility and lack of fellow-feeling have made the American society a true waste land. Tommy always strives for financial success maintaining his feeling of love and affection. There is only one reality that is American dream, which he baffles to achieve but "grows as a person, recalling THE RISE OF SILAS LAPHAM in the previous century" (Nagel, 2007). Wilhelm's biological father doesn't care about him and not interested to be involved in his son's destitute condition. He has ability to assist his son but continuously denied of helping him. In such a condition, he takes shelter in a father - figure, Tamkin who eventually murders his (Wilhelm) dream, eluding with his last means. He depends on a wrong person who is making delay to go to market and talking about the abstract things of life; actually he is always planning a plot to murder Wilhelm successfully. The idol that America worships is materialism and due to this materialism Tommy estranges from his family as well as from mankind. Henceforth, it sprouts the bestial sense of people which persuades to commit murder, either physically or psychologically. It seems that "the world is full of murderers. So it's not the world. It's a kind of hell" (Bellow, 1996, p.71). Hence, it can be said that our

protagonist, Wilhelm symbolizes the simple-hearted American common people at the capitalist society and the rest characters symbolize the exploiter, money - minded as well as successful commercial people of that society. 


\section{Acknowledgement}

The author are greatly thankful to Mr. Md. Ziaul Haque, Senior Lecturer, Department of English, Sylhet International University, Bangladesh for his valuable suggestions and sharing knowledge throughout the preparation of the research.

\section{References}

[1] Barry, P., BEGINNING THEORY: An introduction to literary and cultural theory (New York: Manchester University press, 2002).

[2] Bellow, S., Seize the Day (U.S.A.: Penguin Books, 1996).

[3] Boeree, C. G., Sigmund Freud. (2009). Retrieved from http://webspace.ship.edu/cgboer/freud.html

[4] DelVesco, A., (February, 2011). "A Novel Failure: The Unsuccessful Story of Tommy Wilhelm", Seize the Day, Retrieved from http://www.studymode.com/essays/Seize-The-Day-600902.html

[5] Glencoe Literature The Reader's Choice: American Literature, Texas Ed. (New York: McGraw hill companies, 2000).

[6] Goldman, L. H., Saul Bellow's Moral Vision: A Critical Study of the Jewish Experience (New York: Irvington Publishers, 1983).

[7] Green, Green's blog, A Critical Reading of Seize the Day, Posted at September 27 , 2012. http://www.greenzblog.com/literature/seize-the-day/

[8] Literary Articles, Seize the day by Saul Bellow as an ethnic novel, Retrieved from http://literaryarticles.blogspot.com/2010/02/seize-day-by-saul-bellow-as-ethnic.html

[9] Miller, A., Death of a Salesman (New York: Penguin Books, 1961).

[10] Nagel, James (2007). THE AMERICAN NOVEL: American dreams reality or myth. Retrieved from http://www.pbs.org/wnet/americannovel/ideas/american_article.html

[11] Perkins, G. \& Perkins, B. (Eds.). The American Tradition in Literature. ( $9^{\text {th }}$ Ed.). (New York: McGraw-Hill Humanities, 1999).

[12] Roof Beam reader. (27 Sep., 2012). Review: Seize the Day by Saul Bellow. Retrieved from http://roofbeamreader.com/2012/09/27/review-seize-the-day-by-saul-bellow/

[13] Shatzky, J., and Taub, M. (Eds.). Contemporary Jewish-American Novelists: A Bio-Critical Sourcebook. (London: Greenwood press, 1997).

[14] Shukla, S., and Shukla, A. (Eds.). (2006). Migrant Voices in Literatures in English. Retrieved from http://books.google.com.bd/books?id=zqKmzNpKFGQC\&printsec=frontcover\&source=gbs_ge_summary_r\&cad=0\#v=onepage\&q $\& \mathrm{f}=$ false.

[15] The American Heritage Dictionary of the English Language. $4^{\text {th }}$ Ed. (New York: Houghton Mifflin Company, 2000).

[16] The middle stage: Essays on Indian and world literature. (2006). Retrieved from http://middlestage.blogspot.com/2006/09/on-saulbellows-seize-day.html

[17] The Post-war United States, 1945-1968. Para. 3. Retrieved from http://www.loc.gov/teachers/classroommaterials/presentationsandactivities/presentations/timeline/postwar/

[18] Vaughan, C., Images of American Empires in the novels of Saul Bellow, Saul Bellow Journal, 21 (1-2), 2005.Retrieved from http://www.highbeam.com/doc/1G1-188740459.html 